\title{
BIOPOTENTIALS OF MANGROVES
}

\author{
María Soledad Morales-Covarrubias*, Noemí García-Aguilar and Ana Carmela Puello-Cruz \\ Centro de Investigación en Alimentación y Desarrollo A. C., Unidad Mazatlán en Acuicultura y Manejo Ambiental, \\ Avenida Sábalo Cerritos s/n, Mazatlán, 82112, Sinaloa, Mexico
}

http://doi.org/10.35410/IJAEB.2019.4445

\begin{abstract}
Since ancient times and throughout the world, mangroves have been used as traditional medicine. They are biochemically unique producing a wide array of novel natural products such as biologically active antimicrobial compounds. Their anti-inflammatory, anticancer and other therapeutic properties are well documented and several species of mangrove are used in traditional medicine practices to treat a number of human and animal diseases. Ethnomedicines are recognized by World Health Organizations effective therapeutic agents with special application to aquaculture due to the loss of antimicrobial efficiency and the increasing resistance of pathogens to antibiotics. Use reduction of synthetic antibiotics is considered a priority as incidences of drug resistant bacteria and viruses have increased substantially. Considering all the benefits that mangrove forests represent, we must examine and protect them in order to provide sustainable exploitation. The present review highlights the potential use of mangrove extracts in pharmaceutical, nutraceutical, agriculture and more specifically in aquaculture.
\end{abstract}

Keywords: Mangrove, bioactive, ethnomedicinal, aquaculture.

\section{INTRODUCTION}

Mangroves cover three-fourths of the coastline of Africa, Australia, Asia and America. The most extensive mangrove forests are in the Indo-Pacific region and are located in their major rivers delta systems. The largest mangrove areas are found in Indonesia, Nigeria and Australia. Worldwide, there are 84 mangrove species, 70 of them considered true mangroves and the other 14 are semi-mangrove. Only India has identified 22 genera of mangrove with 55 species approximately (Bakshi et al., 2018).

Distributed across121 tropical and sub-tropical countries they extend over 15.5 million hectares and the largest extension of unexploited mangrove habitat can be found in Indonesia. Their government developed a project entitled "Bioprospecting" that promotes mangrove biodiversity, so that its possible application to agriculture and medicine can be managedin a sustainable way. Mangroves grow along coastal estuarines and form thickets of trees that tolerate high salinity and water-filled soils (Bandaranayake 1998; Chapman 1976; Julkipli et al., 2018; Kathiresan \& Rajendran 2005).

They develop well under axonic soil conditions as their specialized structures facilitate gases exchange. Also, they are one of the world's most productive ecosystems and are known for 
their natural reservoir of nutrients, mainly organic carbon and trace metal s(Kumar \& Nath 2011; Reverter et al., 2017; Upadhyay et al., 2002). Ethnomedicinal practices include plants and plant based metabolites for human, veterinary and aquaculture health (Reverter et al., 2017).

Under hostile conditions, mangroves have developed alterations in their physiological processes, resulting in the synthesis of novel chemical compounds. Some pharmacological properties are expressed in these phytocompounds or secondary metabolites that have been used in traditional treatments for ailments (Das \&Thatoi 2014).Plants and particularly mangroves are one of the richest sources of traditional and modern medicines, and are also used as pharmaceutical intermediates and chemical entities for synthetic drugs, and still to this day as insecticides and pesticides (Bandaranayake,1998;Das \& Thatoi, 2014).

Worldwide, aquaculture production has increased significantly over the last ten years resulting in an increased demand in the market, yet one of the main concerns are diseases in this industry. Aquaculture in the food industry represents the fastest overall growth and is an important global seafood source (Nadaranjah\&Flaaten, 2017). Food and Agriculture Organization, 2019, reported that by 2021 aquaculture will overtake fisheries production. The controlled culture conditions of aquatic organisms is of the utmost importance for sea and freshwater fishes, mollusks, crustaceans as well as plants (Avenido \& Serrano, 2012a).

Throughout the last decade viable methods have been developed to produce over 580 aquatic species, highlighting an enormous wealth of genetic diversity. Aquaculture faces risks from pollution (agricultural and industrial waste), temperature variability (global warming) and diseases (bacterial, protozoan and fungal), (Rajagopal et al., 2017). Over the past 10 years, shrimp culture has been associated with high prevalence of bacterial diseases and extensive use of antibiotics for their control, resulting in antibiotic resistance by many pathogenic bacteria (Morales-Covarrubias et al., 2018).

Herbal treatments that exhibit bactericidal activity can be used in aquaculture. Plant based therapeutics are beneficial because they are not associated with many side effects as opposed to synthetic antibiotics(Saranraj \& Sujitha, 2015). Although plants produce and store a large number of primary and secondary metabolites, the most relevant for natural products are the secondary metabolites, since they are the source of biologically active compounds.

The chemical composition, concentration and localization in plants vary according to the species and sources (Iwu et al., 1999; Manilal et al., 2009).Due to the organic content, secondary metabolites, elemental compositions and wide range of medicinal properties, their bioprospecting potential was recently explored (Bakshi et al., 2018).Secondary metabolites such as alkaloids, phenolics, steroids and terpenoids are characteristically recognized as having toxicological, pharmacological and ecological importance, however, these studies were restricted to mangroves inmuddy regions (Babuselvam et al., 2012; Saranraj \& Sujitha, 2015). Bakshi et al. (2018) reported that mangroves possess a number of phytoalexins and phytoanticipin compounds which act as defense mechanisms. Mangroves possess higher antibacterial potency than salt marsh halophytes (Bakshi et al., 2018; Bandaranayake, 1998; Saranraj\&Sujitha, 2015).

Many mangrove species contain sources of bioactive metabolites and compounds that control microbial growth and provide new sources of antiviral, antibacterial, antifungal and insecticide for pharmacological use and can be considered as an alternative medicine in aquaculture as their extracts have effective inhibitory activity against pathogens (Vadlapudi \& Naidu, 2009). 
Vol. 4, No. 05; 2019

ISSN: $2456-8643$

\section{MANGROVE - PHARMACEUTICALS}

Mangrove trees exposed to low oxygen concentrations and greater limitation of nutrients adapt to this unique habitat. These conditions promote the synthesis of secondary metabolites released by the trees and organisms associated to them (Patra\&Mohanta, 2014). Preliminary studies suggest that mangrove extracts have antibacterial activity against bacterial strains (Staphylococcussp., Escherichiacoli and Pseudomonasp.), antibiotic resistant against bacterial strains (Staphylococcussp. and Proteus sp.) and bioactive compounds that control microbial growth (Babuselvam et al., 2012; Bakshi et al., 2018; Manilal et al., 2009; Saranraj \& Sujitha, 2015; Abeysinghe et al., 2006).

The different antimicrobial activity of mangroves may result in the amount of chemical components such as coumarins, flavonoids and saponins (Aljaghthmi et al., 2018; Bakshi et al., 2018; Chandrasekaran et al., 2009). The antibacterial activity of vegetable constituents such as essential oils of phenol, quinines, flavonoids, tannins and terpenoids have been reported (Bakshi et al., 2018; Das \& Thatoi, 2014). Also, they are asource of mosquito larvicides, antifungal, antiviral, anti-cancer and anti-diabetic compounds, and cholesterol-regulators and also serve as a combat for cardiac disorders, dementia and tumors.

Two mangrove species (Rhizophora mucronata and Avicennia marina) are reported to act against insulin inhibitors. Extracts from two other mangrove species (Bruguiera cylindricaland

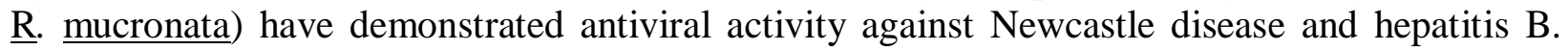
Methanolic extracts obtained fromthe leaves of Rhizophora lamarckii, Avicennia officinalis and Sesuvium portulacastrum prevent the development of Alzheimer's disease by protecting against cholinesterase inhibitors. Both Bruguiera gymnorrhiza and Excoecariaa gallocha exhibited antifungal activity and Bruguiera sexangula exhibited antibacterial activity (Aljaghthmi etal., 2018; Suganthy et al., 2009; Saranraj\&Sujitha, 2015).

Saranraj et al. (2010) evaluated the antibacterial potentiality of ethanol and ethyl acetate solvent extracts of mature leaves of Acalypha indica against nine pathogenic bacterial isolates viz., Staphylococcus aureus, Bacillus subtilis, Bacillus cereus, E. coli, Salmonella typhi, Shigella flexneri, Klebsiella, Streptococcus pneumoniae, Vibrio cholerae and Pseudomona saeruginosa. The turbidity of the bacterial inoculums was compared with 0.5 McFarland standards and the antibacterial potential of $\underline{A}$. indica ethanol extract was determined using the Agar well diffusion method. The ethanol extract of $\underline{\mathrm{A}}$. indica $(100 \mathrm{mg} / \mathrm{ml})$ achieved a maximum zone of inhibition $(30 \mathrm{~mm})$ against $\underline{\mathrm{P}}$. aeruginosa, $\underline{\mathrm{E}}$. coliand $\underline{\mathrm{B}}$. subtilis, while $\underline{\mathrm{S}}$. aureus exhibited less zone of inhibition $(100 \mathrm{mg} / \mathrm{ml})$.

The studies on A. marina focused mainly on flavonoids, tannins, polyphenols and phytosterol compounds, all of which have anti-inflammatory, antioxidant, antiviral, antifungal and antibacterial properties. At various stages during the replication cycle, tannins, polyphenols, lignin and anthraquinonoid are able to inhibit many viruses that could potentially be antiviral agents (Jassim\&Naji, 2003). Still, it is important to evaluate their regulatory limit, permissible tolerance and toxicity levels before their application as viable therapeutic alternatives (Bandaranayake, 1998; Manilal et al., 2009).

Antibacteriophages, antibacterial and antifungal activities from a mixture of extracts (roots, cotyledons, leaves and stems) of $\underline{\text { A }}$ marina were evaluated by Khafagi(2003), who also 
observed that aqueous extracts of sprouts and roots had antibacteriophages activity using coliphage against $\underline{E}$. coli NRRL B-3704. Methanolic extracts of $\underline{A}$. marina were the most effective at inhibiting the growth of bacterial pathogens of humans and clinical isolates. $\underline{S}$. aureus, Candida albicans and Candida tropicalis were better than $\underline{\mathrm{A}}$. marina at suppressing fungal growth (Manilal et al., 2016).

Ethyl acetate extracts of tender leaves of Holigarnaar nottiana inhibited the growth of three human pathogens (모 aureus, Micrococcus luteus and Streptococcus mutants). In the clinical isolates, the greatest inhibition zone was against $\underline{E}$. coli and the lowest was against Pseudomona sp. (Manilalet al., 2014). Extracts of Rhizophora apiculata roots are effective as mosquito larvicides, and when applied to the skin act as an effective repellent against the adult mosquito Aedes aegypti (Patra \& Thatoi, 2011).

Sánchez-Perera et al. (2007), compared different determinations and methodologies such as gravimetric, colorimetric, gas chromatography/mass spectrometry (CG/EM), polyphenols fractions and HPLC to evaluate the aqueous extract of Rhizophora mangle bark and identified $54.8 \%$ polyphenolic structures. In the same study, polyphenols were found to contain $80 \%$ of condensed and $20 \%$ of hydrolyzed tannins, also identified were epicatechins, catechins, clorogenic acid, gallic and ellagic acid.

Manilal et al. (2015a), evaluated in vitro antimicrobial activity of $\underline{\mathrm{R}}$. mucronataextracts in different polar and non-polar solvents (hexane, chloroform, ethyl acetate, ethanol, methanol and phosphate buffer saline) and achieved the best results with methanol. Antibiotic assays against potential human pathogens ( $\underline{\mathrm{S}}$. aureusMTCC96, $\underline{\mathrm{S}}$. mutansMTCC890, Klebsiella pneumonia MTCC109, Shigella flexneriMTCC1457, M. luteus MTCC106 and Vibrio mimicusMTCC4434) were successfully controlled. aureus presented the highest inhibition. Ethanone 1-2-hydroxy-5methylphenil was the main constitute identified from the extracts, and is thought to enhance antibacterial activity. The extracts of this mangrove are commonly used in India and south-east Asia for controlling diabetes, curing stomach diseases, swelling, cuts and ulcers. Recent studies suggest that they also reduce blood glucose levels and actas an oxygen blood stabilizer that prevents stress during oxidation (Aljaghthmi et al., 2018; Joel \& Bhimba 2010).

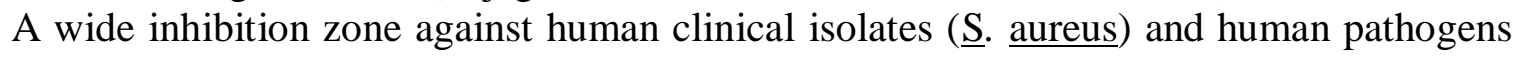
(C. albicans) was demonstrated with ethyl acetate, ethanol and methanol extracts of tender foliage of Sonneratia alba (Manilal \& Idhayadhulla 2014a). These extracts have high antibacterial effects against gram positive bacteria but do not respond to Gram negative (Manilal et al., 2015b).Manilal et al.(2014b), obtained the extract of twelve mangroves using ethyl acetate solvent and identified metabolites against pathogenic bacteria that affect humans. Calophyllum inophyllum formed the greatest inhibition zone against $\underline{S}$. aureus. Ethyl acetates were the best solvents for extracting a high proportion of the main metabolites, these could also act as a possible chemical defense mechanism against microorganisms.

Extracts of Sonneratia apetala gave high antibacterial activity and were also able to synthesize silver nanoparticles. This is regarded a low cost and ecologically friendly antibacterial that is potentially a promising remedy particularly for bacteria that is resistant to antibiotics (Nagababu \& Rao, 2017). Simlai et al. (2014), evaluated extracts of Sonneratia caseolaris sing methanol as solvent to determinate the antibacterial and ant oxidative activities against $\underline{E}$. coli, Proteus vulgaris, $\underline{B}$. subtilis and Bacillus coagulans. Maximum activity against $\underline{B}$.

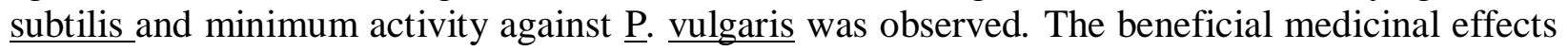


resulting from the combination of secondary metabolites such as phenolic, flavonoids, tannins, alkaloids and saponins are capable of curing bacterial diseases.

Mangrove ecosystems have immense biotechnology potential. Studies carried out on endophytes that live asymptomatically inside mangroves have exhibited antimicrobial, antineoplastic, antioxidant, antidiabetic, immunosuppresses, antithrombotic anti-inflammatory and anti-Alzheimer's activities (Salini, 2015). Endophytic microorganisms (fungus, bacteria and actinomycetes) are recognized as new and little-explored sources of bioactive compounds. New chemical isolation of metabolites such as alkaloids, carbohydrates, liginins, polysaccharides, fatty acids, phenolic compounds (polyphenols, flavonoids, xanthones and coumarins) were recently identified (Salini, 2015; Eldeen \& Effendy, 2013). Several bioactive metabolites are derivatives of mangrove fungi, in particular endophytes which are widely used in the pharmaceutical and nutraceutical industry for the production of antimicrobial, anticancer, antioxidant and other agents (Thatoi et al., 2013).

\section{MANGROVE - NUTRACEUTICALSAND TRADITIONAL FOODS}

Traditionally, culinary culture is enriched with different mangrove parts such as leaves, stems, stalks, pits, barks, berries, roots and seeds, all of which are used to enhance human and animal health due to their bioactive compounds. The chemical composition of mangroves include antioxidants, squalene, triterpenoids, phytol, tannins, alkaloids, flavonoids, steroids and phenols, all of which are considered key for many metabolic processes (Kumar \&Nath, 2011).

Mangroves provide phytonutrients that protect against pathogens, for example flavonoids and tannins extracted from mangrove leaves activate pancreas activity. The leaves of Ceriops decandra have antidiabetic properties that can control blood sugar levels and have less side effects than commercial drugs. However, the ingested amounts need to be regulated because when administered in excess can be toxic (Aljaghthmi et al., 2018; Nabeel et al., 2010).

Since humans are known for consuming medicinal plants as part of their diets or as a cure for ailments, mangroves are a cheap and nutritionally rich source for sheep, goats, buffaloes and camels to graze on. Also, they are suppliers of fishery product such as fish, shrimp, prawn, crab, mollusk and so on. Their leaves and fruits are edible and can be used to produce beverages. Honey production is also known to benefit as they serve to attract bees (Kathiresan, 2012).

It has been suggested that the fruit extract of Bruguiera gymnorrhiza acts as a preservative and it also exhibits antimicrobial activity. This extract combined with chitosan inhibits bacterial growth of peeled shrimp stored at temperatures of $10^{\circ} \mathrm{C}$, with the added advantage that they are natural products. This plant has high carbohydrate levels and can be added to baking products or can be mixed with rice and coconut. Its fruit are large, high in protein and lipid levels and can be eaten whole except for the skin (Rosulva et al., 2014). Avicenia alba, is also edible and is eaten with coconut and crackers. Sonneratia alba is used for syrup and drinks while $\underline{\mathrm{R}}$. Mucronata and $\underline{\text { Acrostichum aerum are used as vegetables (Priyono et }}$ al., 2010).

\section{MANGROVE - TRADITIONAL MEDICINAL PLANT}


The use of mangroves in medicine reflects their importance to mankind. Traditional cultures have gathered practical knowledge about the medicinal properties of plants including mangroves. This information was passed on from generation to generation, however, much has now been lost as very little was documented (Saranraj \& Sujitha, 2015).

Extracts and biologically active compounds isolated from plant species have been used as preventive and curative medicine for over 2000 years, and within the last decade, natural alternatives have been explored as a possible bactericidal treatment for aquaculture (Saranraj \& Sujitha, 2015; Torres-Rojas et al., 2007; Ramírez \& Castaño, 2009; García-Aguilar, 2013; Morales-Covarrubias et al., 2016).

Plant extracts with medicinal potential represent a valid substitute for the treatment of different ailments and diseases (Laith et al., 2012).

Nowadays, plants play a leading role in primary healthcare and remedies such as therapeutic solutions in many developing countries (Alim et al., 2009).

The most common procedures for transforming herbal products to conventional medicines are by infusion and the decoction of vegetable tissues to extract their active substances. They need thorough rinsing to eliminate salt, dust, soil, dirt and so on and they can be grinded to a powder or alternatively they can be chopped, left whole, or in part, that can be used solely or in combination. When water ebullition point $\left(100^{\circ} \mathrm{C}\right)$ is reached and makes contact with fresh or dry plants, the vegetable cells explode and discharge active substances (Alim et al., 2009).

The scientific term for this is "aqueous extracts" and its main advantage is the provision of simple and fast in situ preparations (Citarasu, 2010). Other extraction methods include the use of different solvents such as ethanol, methanol, chloroform and ethyl acetate by soxhlet apparatus. It is important to standardize the amount of plants, boiling and cooling time of water (Laith et al., 2012; Meléndez-Rentería et al., 2009). Calophyllum inophyllum nut oil is used to treat rheumatism, scabies, ringworm and dermatosis (Aljaghthmi et al., 2018).

Leaves of the mangrove Bruguiera species are used to reduce blood pressure and the leaves of Acanthus ilicifolius are used to treatrheumatic disorders. Seeds of the Xylocarpus mangrove have antidiarrheal properties. Avicennia species have a tonic effect. Ceriops species produce hemostatic activity. The bark of the Rhizophora species contains astringent, antidiarrheal and antiemetic agents. Mangroves can even be used astherapeutic treatments for incurable viral diseases such as AIDS (Regalado et al., 2016).

Poultice of seeds of Avicennia officinalis are commonly applied to treat mature ulcers and speed up the suppuration of boils and abscesses. The roots of this mangrove has an aphrodisiac effect. The branch is considered diuretic and used to treat scabies and it is also helpful in the treatment of rheumatism, asthma and snake bites. Poultices prepared from the fruit are used to heal tumors. Adding sugar to the decoction of the tree has been used for dyspepsia. The exudate (resin) of the bark is used to prevent ulcers, as a contraceptive means, as an antiinflammatory, as an antioxidant and as a protection against cancers (Das et al., 2018).

\section{MANGROVE - AGRICULTURE APPLICATIONS}

Mangroves act as effective sediment trappers that support nutrient recirculation systems such as carbon and nitrogen, and are possibly the only trees that recycle that in turn allows other 
organisms to assimilate it. They also absorb and retain highly poisonous heavy metals (Kathiresan, 2012).The endophytic bacteria of mangroves has been successfully used in rice cultivation where it enhances root and shoot growth, weight and chlorophyll content (Deivanai et al., 2014)

\section{MANGROVE - AQUACULTURE APPLICATIONS}

Mangroves in some regions are important because they offer a fish and shrimp larvae source. On the other hand, the shrimp aquaculture industry in many world regions is beset by disease, mostly due to the species of the genus Vibrio, such as $\underline{\mathrm{V}}$. harveyi, $\underline{\mathrm{V}}$. parahaemolyticus and $\underline{\mathrm{V}}$. vulnificus. The high density of animals in hatchery tanks and pond farms facilitate the spread of pathogens as protein-rich feed is regularly applied. Morales-Covarrubias (2010) reported that the interaction between microbes, animals and the environment at intensive production-scale have been considered primarily from a clinical pathology perspective rather than treating the underlying cause. When farmers detect sources of pathogenic microorganisms, they apply antimicrobial compounds to feeds and water, and use large quantities of prophylactics (baths or injections).Sometimes, they even apply these procedures when pathogens are not present.

This can lead to an increase in Vibrio and presumably the presence of other bacteria that may increase antimicrobial resistance and produce more virulent pathogens that tend to mutate to more virulent forms (Le et al., 2005).Even non-stressed shrimp become more susceptible to disease (Babuselvamet a, 1 2012; Le et al., 2005; Morales-Covarrubias \& Gómez-Gil, 2014).

Unconsumed food and faeces of the treated organisms end up in the sediment and create selective pressure that cause changes in the composition of the micro flora and microfauna ( $\mathrm{Tu}$,et al., 2010). Natural or synthetic antibiotics must be considered safe for the organisms before they can be used as chemotherapeutic agents for the treatment of infectious bacterial diseases. An increase in antibiotic-resistant strains reduce medical options for curable diseases. Antibioticresistance has been widespread, due in part to clinical overuse and misuse, however, natural processes of horizontal transfer of genes and mutation events that allow genetic changes within microbial populations have always occurred (Watts et al., 2007).

Aquaculture systems naturally contain large numbers of different microorganisms that combine the current and past use of antimicrobials, probiotics, prebiotics and other treatments. These aquatic systems have been described as"genetic reactors" or "hotspots" for antimicrobial resistant genes as significant genetic exchanges can occur and may affect the future evolution of resistance. Estimates suggest that $90 \%$ of seawater bacteria are resistant to at least one or more antibiotics while up to $20 \%$ are resistant to as many as five. That is to say, as dependence on aquaculture increases, sources and reservoirs of antimicrobial resistance need to be identified (Julkipli et al., 2018).

The use of antimicrobials in aquaculture is regulated by many factors such as government legislation and policy, available pathogens, treatment time, disease status of the host and parameters (salinity, temperature, photoperiod, etc.).Alternate forms of research into disease prevention require adequate management practices and reverting to conventional natural options in order to improve quality products from aquaculture (Vignesh et al., 2011). 
It may well be economically viable to investigate the mentioned bioactive compounds as they may have the added advantage of being biodegradable. They can be applied to aquaculture disease management, antifouling and biopharmaceuticals (Manilal et al., 2010; Manilal et al., 2009).

In order to estimate the antimicrobial activity against some bacterial strains (E. coli-

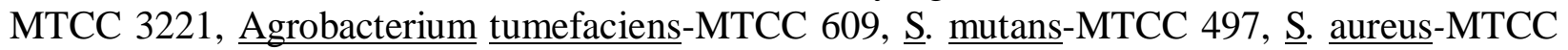
7405) and three fungal strains (Aspergillus flavus-MTCC 1884, Tricophyton rubrum-MTCC296, Fusarium oxysporum-MTCC 284), extraction using a variety of solvents from the mature healthy leaves of ten mangroves were obtained. A number of interesting findings came to light, between antimicrobial activity, solvent and mangrove species. Ethyl acetate and acetone extracts of $\underline{A}$.

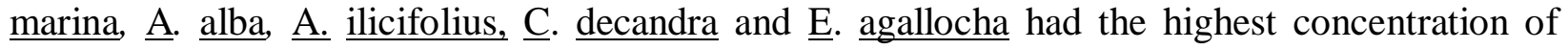
antimicrobials. A. marina presented the highest inhibition growth rate against $\underline{\mathrm{S}}$. aureus and $\underline{\mathrm{S}}$. mutans. Hexane extraction of A. ilicifolius and E. agalloch ayielded the highest antimicrobial activityagainst $\underline{S}$.aureus while $\underline{A}$. marina suppressed the growth of $\underline{E}$. coliand $\underline{S}$. aureus.A. alba,

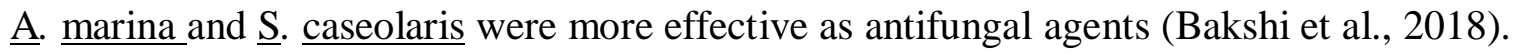

Considering the pharmacological potential of mangrove extracts, more specific studies are required so that the best options can be identified and selected. Acanthus ilicifolius was tested for a different range of biological activities including antimicrobial activity against five Vibrio pathogens. Extracts of this mangrove with methanol solvent suppressed the growth of $\underline{\mathrm{V}}$. alcaligenes (MTCC 4442), $\underline{\mathrm{V}}$. vulnificus (MTCC 1145) and $\underline{\mathrm{V}}$. alginolyticus (MTCC 4439). The lethal concentration of toxicity for free-swimming nauplii of Artemia salina (Linnaeus) was 475 $\mu 1$ while marine acclimatized Oreochromis mossambicus resulted in $100 \%$ mortalities at 300 $\mu \mathrm{g} / \mathrm{ml}$. Lastly, Patella vulgate (common limpet) was used to evaluate the antifouling activity of the extracts and with a concentration of $14.8 \mathrm{mg} / \mathrm{ml}$ was enough to inhibit the adherence of the animals foot capacity (Manilal et al., 2009).

Ethyl acetate extracts obtained from this mangrove contained antimicrobial activity $\underline{\text { n }}$ vitro against shrimp pathogen Vibrio harveyi and fish pathogen Aeromona hydrophila (Sreenivasa et al., 2015).

Extracts of A. marina using methanol as a solvent gave antibacterial activity against all

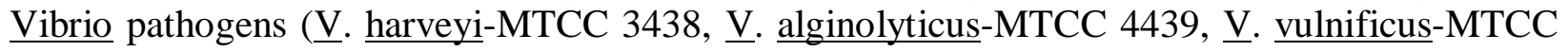
$1145, \underline{\mathrm{V}}$. parahaemolyticus-MTCC $451, \underline{\mathrm{V}}$. alcaligenes-MTCC 4442). The lethal concentration of the extracts for free-swimming nauplii of Artemia salina was $318 \mu$ l. The ichthyotoxic activity(lethal concentrations) for marine acclimatized Oreochromis mossambicus fingerlings was established at $318 \mu \mathrm{g} / \mathrm{ml}$. Antifouling properties were evaluated with Patella vulgate (common limpet) a concentration of $6 \mathrm{mg} / \mathrm{ml}$ was enough to affect the foot adherence of this mollusk, while a concentration of $10 \mathrm{mg} / \mathrm{ml}$ produced $100 \%$ mortalities. An important consideration is that these extracts can be used as biopharmaceuticals with the advantage that they are biodegradable (Morales-Covarrubias et al., 2018). The aqueous extract of $\underline{\mathrm{A}}$. marina leaves act to protect the immune system and thwart vibrio resistance in Amphirion sebae (Choudhury et al., 2005).

Abou-Elela et al. (2009), used chloroform and ethanol to obtain extracts from seeds, leaves, stems and roots of $\underline{\mathrm{A}}$. marina and evaluated them against pathogenic bacteria $(\underline{\mathrm{P}}$. aeruginosa, $\underline{\text { V. fluvialis, }} \underline{\mathrm{V}}$. vulnificus, $\underline{\mathrm{S}}$. faecalis, $\underline{\mathrm{E}}$. coli, $\underline{\mathrm{S}}$. aureus and $\underline{\mathrm{B}}$. subtilis). Analyses of the chemical composition included antimicrobial agents such as 
flavonoids, triterpenoids, lignin and tannin. Chloroform extracts of seeds exhibited significant antibacterial activity against most pathogens including Vibrio fluvialis suggesting that these extracts can be safely used in aquaculture. When applied to Nile tilapia (Oreochromis niloticus) satisfactory results were obtained.

Dhayanithi et al. (2015), used the extract of $\underline{\mathrm{A}}$. marina as a dietary supplement in the clown fish Amphiprion sebae against $\underline{\mathrm{V}}$. alginolyticus. After the challenge, mortality in all the treated groups was lower than that of the infected untreated group. Survival rates of $85 \%$ and $80 \%$ were observed in the group fed on $4 \%$ and $8 \%$ respectively of the supplemented diet.

Manilalet al. (2016),tested foranti-Vibrio activity of $\underline{A}$. marina extracts and found a high inhibition growth for $\underline{\mathrm{V}}$. vulnifus followed by $\underline{\mathrm{V}}$. alginolyticus, thus suggesting a promising biotherapeutic approach towards controlling shrimp Vibrios.

Extracts of unspecified $\underline{A}$. officinalis mangrove tissue using methanol as a solvent presented an inhibition zone against shrimp $\underline{\mathrm{V}}$. parahaemolyticus and $\underline{\mathrm{V}}$. alginolyticus, and to the multiresistant clinical pathogen $\underline{P}$. aeruginosa. Screening tactics for identifying traditional ecological knowledge are useful to determine bioactive compounds that could be relevant to the pharmaceutical and agrochemical industries (Manilal et al., 2010).

Considerably good results were achieved when methanol extracts of Bruguiera cylindrical were used to test for antimicrobial activity against $\underline{\mathrm{V}}$. alcaligenes (MTCC 4442) and $\underline{\mathrm{V}}$. alginolyticus (MTCC 4439).The toxicity of the extracts was evaluated with free-swimming nauplii of Artemia salina (Linnaeus) at a lethal concentration of $410 \mu$ l. Fingerlings of $\underline{\mathrm{O}}$. mossambicus acclimatized with marine water were used to determine the ichthyotoxic activity and a concentration of $250 \mu \mathrm{g} / \mathrm{ml}$ produced $100 \%$ mortality. Lastly, the antifouling activity based on the adherence or shrinkage of the Patella vulgate (common limpet) foot was tested. A concentration of $11.5 \mathrm{mg} / \mathrm{ml}$ gave a fouling rate of $20 \%$ with a $50 \%$ regaining rate (Manilal et al., 2009).

Eldeen \& Effendy. (2013), worked with extracts of Ceriops tagal and found that they contained antibacterial properties against five fish and shrimp pathogens (A.hydrophila, $\underline{\mathrm{V}}$. $\underline{\text { harvey, }} \underline{\mathrm{V}}$. alginolyticus, $\underline{\mathrm{V}}$. vulnificus and $\underline{\mathrm{V}}$. parahaemolyticus) while methanolic extracts were found to be similar to the antibiotic Streptomycin. Penaeus vannamei fed on pellets coated with extract of Ceriops. tagalleaves provided antiviral activity protection(Sudheer et al., 2011; Sudheer et al., 2012).

Nabeel et al. (2010), reports that Derris trifoliata is used to narcotize fishes.

Bacterial diseases such as motile aeromona septicemia (MAS) caused by $\underline{\text { A. hydrophila }}$ may possibly be a threat to ornamental fish cultures. In the case of infected Amphiprion sebae, ethanol extract sof Excoecaria agallocha leaves at $10 \mathrm{mg} \mathrm{kg}-1$ were administrated and survival improved (Dhayanithi et al., 2012).

Satisfactory results were achieved by Manilal et al. (2009), who found that using chloroform extract of Finlaysonia obovata leaves provided good antibacterial protection against fish pathogens. Also, Babuselvam et al. (2012), determined that Salichornia brachiate exhibits higher antibacterial efficiency than $\underline{R}$. mucrana and can potentially be used in aquaculture while, Lim et al. (2006), identified the antibacterial activity of mangroves as a means to combat fish pathogens. These findings suggest that plant extracts can be applied to aquaculture.

Extracts of tender leaves of Holigarna arnottiana were evaluated against Vibrio strains

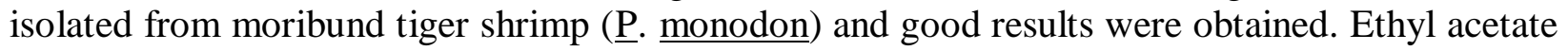


were found to be the best solvent for extracting the antibacterial compounds of $\underline{H}$. arnottiana. The highest inhibition ring displayed was with $\underline{\mathrm{V}}$. alcaligenes followed by $\underline{\mathrm{V}}$. alginolyticus, resulting in growth impediment in all shrimp Vibro isolates (Manilalet al., 2014).

Methanol extracts from unspecified tissue of Rhizophoras apiculate were evaluated against shrimp Vibrios pathogens and, exhibited suppressed growth in $\underline{\mathrm{V}}$. vulnifus, $\underline{\mathrm{V}}$. harveyi, $\underline{\mathrm{V}}$. alcaligenes and $\underline{\mathrm{V}}$. alginolyticus and against multiresistant clinical pathogens $(\underline{\mathrm{S}}$. aureus, $\underline{\mathrm{P}}$.

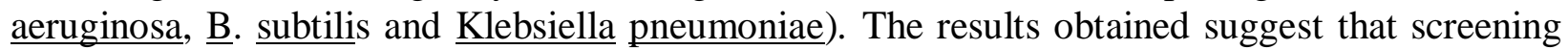
tactics based on ecological knowledge are useful to determine which bioactive compounds could be relevant to the pharmaceutical and agrochemical industries (Manilal et al., 2010).

Raju \& Sreeramulu (2017) reported that crude extracts from the bark and collar of $\underline{R}$. mucronata showed the maximum inhibition growth activity against $\underline{E}$. coli, $\underline{\text { Citrobacter freundii, }}$

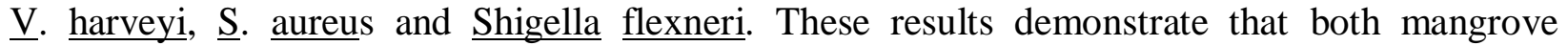
extracts show antibacterial activity against pathogens found in Mugil cephalusso their application can potentially be considered in the fish culture industry.

Using a wide variety of solvents (chloroform, hexane, ethyl acetate, methanol and distilled water), extracts of mangrove leaves were obtained and evaluated on lobster larvae against $\underline{\mathrm{V}}$. harveyi and $\underline{\mathrm{V}}$, campbellii isolated from farm water (Baskaran\& Mohan, 2012).

Manilal et al. (2015), also evaluated in vitro antibacterial activity of $\underline{R}$. mucrata extracts in different polar and non- polar solvents (hexane, chloroform, ethyl acetate, ethanol, methanol and phosphate buffer saline) and found that methanol gave the best results. Antibiotic assays against potential shrimp pathogens $(\underline{\mathrm{V}}$. alginolyticusMTCC4439, $\underline{\mathrm{V}}$. alcaligenesMTCC4442, $\underline{\mathrm{V}}$. vulnificus MTCC1145, $\underline{\mathrm{V}}$. parahaemolyticusMTCC451, $\underline{\mathrm{V}}$. harveyi MTCC3438, $\underline{\mathrm{V}}$.

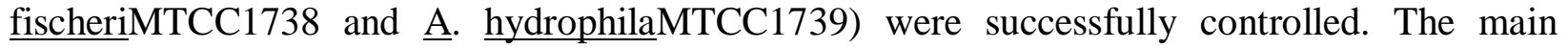
metabolite in the extractwas ethanone1-2-hydroxy-5-methylphenil and it was attributed to antibacterial activity.

Ethanol extracts obtained from the leaves of Salicornia brachiate and $\underline{\mathrm{R}}$. mucronatawere

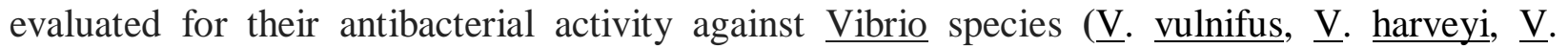
$\underline{\text { alginolyticus, }} \underline{\mathrm{V}}$. anginllarum and $\underline{\mathrm{V}}$. lohi) that affect shrimp, and against fish pathogens ( $\underline{\mathrm{B}}$.

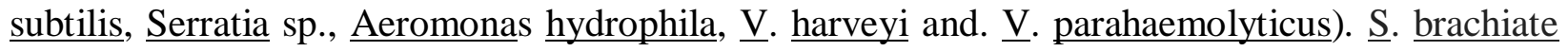
gave good results for shrimp ( $\underline{\mathrm{V}}$. alginolyticus) and fish ( $\underline{\mathrm{V}}$. parahaemolyticus) pathogens. Mangrove extracts can be considered as anti-pathogenic agents for aquaculture, however, further studies are required to evaluate the economic feasibility of producing large quantities of functional extracts (Babuselvam et al., 2012).

Extracts of Sonneratia alba tender foliage obtained with ethyl acetate, ethanol and methanol solvents had strong antibiotic activity against Vibrio of $\underline{\mathrm{P}}$. monodon, and the highest activity was achieved against $\underline{\mathrm{V}}$. alginolyticus. GC-MS analyses of the extracts produced a peak in the analogous bioactive compound Squalene known for its cosmetic properties (Manilal et al., 2015b).

Methanol extracts of Sonneratia caseolaris and $\underline{R}$. apiculata leaves exhibit antibiotic activity against isolated fish bacteria (Klebsiella pneumoniae, Shigella dysenteriae, Enterobacter cloacae, Enterobacter sakazakii, Enterobacter brevis, Chryseobacterium indologenes,

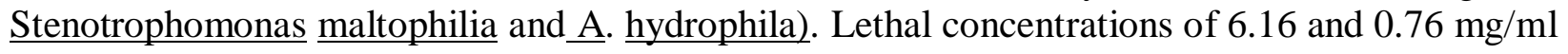
toxicity were observed when brine shrimp larvae were fed on extracts of $\underline{S}$. caseolaris and $\mathrm{R}$. 
apiculata. S. caseolaris provided the most effective antibacterial activity against all gram negative bacteria as previously reported (García-Aguilar, 2013).

The mature leaves of Sonneratia caseolaris were dried, pulverized and the extracts obtained were immersed in $80 \%$ methanol for $72 \mathrm{~h}$. Once elaborated, the pellets were sprayed and fed to the fish.Healthy African catfish (Clarias gariepinus) fed on $\underline{S}$. caseolaris extract exhibited a higher percentage of body weight and better growth than those in the control treatment. Due to its therapeutic potential, $\underline{\mathbf{S}}$. caseolaris extract fed as a supplement to African catfish showed that survival improved after the challenge with Edwardsiella tarda. The immunostimulant properties of $\underline{S}$. caseolaris extract enhanced the white and red blood cell production and reduced blood glucose associated with infection and stress levels in this species (Aznan et al., 2018).

Avenido \& Serrano (2012a) tested the twig extracts of the apple mangrove ( $\underline{S}$. caseolaris $)$ as a growth promoting agent for $\underline{\mathrm{P}}$. monodon since it has an effective immune response to this species. The mangrove extract did not affect growth rate or feed conversion efficiency but survival improved. It promotes the digestion of carbohydrate and protein by increasing the activities of amylase and total protease. This extract could be employed in shrimp culture as a prophylactic practice as well as an immunostimulant with positive effects on growth.

Twig extracts of $\underline{S}$. caseolaris could be used as a prophylactic practice and used to stimulate protein digestion by increasing the activities of trypsin and chymotrypsinin juvenile $\underline{\mathrm{P}}$. monodon. Lipase activity was not at all affected by the apple mangrove extract (Avenido \& Serrano, 2012b).

Organic solvent extracts of mangroves (Aegiceras corniculatum, Aergialitis

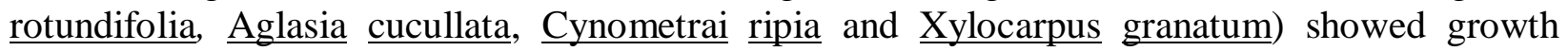
inhibition for six virulent strains of fish bacterial pathogens (A.hydrophila, Pseudomonas

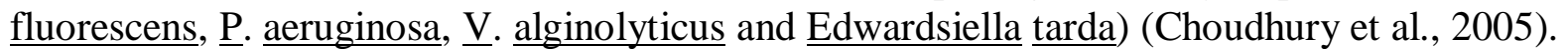

Manilal et al. (2014), obtained twelve mangrove extracts with ethyl acetate and from these six (Acanthus ilicifolius, Calophyllum inophyllum, Cerbera odollam, Derris scandens, Derris trifoliate and Dalbergia candenatensis) showed measurable inhibition zone against shrimp Vibrio pathogens. C. inophyllum surpassed the overall inhibiting microorganisms' growth, resulting in $\underline{\mathrm{V}}$. alginolyticus (MTCC4439) being the most sensitive when compared to the others (‥ alcaligenesMTCC4442, $\underline{\mathrm{V}}$. vulnificusMTCC1145, $\underline{\mathrm{V}}$. parahaemolyticusMTCC451, $\underline{\mathrm{V}}$. harveyi MTCC3438 and $\underline{\text {. }}$ fischeri MTCC1738).

\section{Conflict of Interests}

The authors declare no conflict of interests.

\section{Acknowledgements}

The authors wish to thank Valerie Williams for the English style correction of the manuscript.

\section{REFERENCES}


Abeysinghe, P.D., Wanigatunge, R.P., and Pathirana, R.N. (2006). Evaluation of antibacterial activity of different mangrove plant extracts, Ruhuna. Journal of Science vol. 1, pp. 104112.

Abou-Elela, G.M., El-Sersy, N.A., El-Shenawy, M.A H., Abd-Elnabi and H.A.H. IbrahimH, A.H. (2009). Bio-Control of Vibrio fluvialis in Aquaculture by Mangrove (Avicennia marina) Seeds Extracts," Research Journal of Microbiology,vol. 4, no. 1, pp. 38-48.

Alim, A., Goze, I., Goze, H.M., B. Tepe, B., and Serkedjieva, J. (2009). In vitro antibiotic and antiviral activities of the essential oil and various extracts of Salvia cedronellaBoiss, Journal of Medicine Plants Research, vol. 3, no. 5, pp. 413-419.

Aljaghthmi, O., Heba, H., and Zeid, I.A. (2018). Bioactive Compounds Extracted from Mangrove Plants (Avicennia marina and Rhizophoramucronata): an Overview, Pathophysiology. https://doi.org/10.1016/j.pathophys.2018.09.002.

Aznan, A.S., Lee, K.L., Low, C.F., Iberahim N.A., Wan Ibrahim W.N., Musa, N., Yeong, Y.S., Musa N. (2018). Protective effect of apple mangrove Sonneratiacaseolaris extract in Edwardsiellatarda-infected African catfish, Clariasgariepinus, Fish and Shellfish Immunology, vol. 78, pp. 338-345.

Avenido, P., and A. E. Serrano, A.E. (2012a). Effects of the apple mangrove (Sonneratiacaseolaris) on growth, nutrient utilization and digestive enzyme activities of the black tiger shrimp Penaeusmonodonpostlarvae. European Journal of Experimental Biology, vol. 2, no5, pp.1603-1608.

Avenido, A., and Serrano, A.E. (2012b). Twig extract of the apple mangrove affects the activities of trypsin, chymotrypsin and lipase in postlarval black tiger shrimp Penaeusmonodon at varying feeding frequencies. ELBA Bioflux, vol. 4, no. 2 pp.56-61.

Bakshi, M., Ghosh, S., Ram, S.S., Sudarshan, M., Chakraborty, A., Biswas, J.K., Shaheen, S.M., Niazi, N. K., Rinklebe, J., Chaudhuri, P. (2018). Sediment quality, elemental bioaccumulation and antimicrobial properties of mangroves in Indian Sundarban. Environmental Geochemistry and Health, vol. 41, no. 1, pp. 275-296.

Babuselvam, M., Farook, K.A.M., Abideen, S. Babuselvam, Peer, M.M., Ulthiraselvam. (2012). Screening of antibacterial activity of mangrove plant extracts against fish and shrimp pathogens. International Journal of Applied Microbiology Science, vol. 1, no.3, pp. 2025 .

Bandaranayake, W.M. (1998). Traditional and medicinal uses of mangroves. Mangroves and salt marshes, vol. 2, pp. 133-148.

Baskaran, R., and P.M. Mohan, P.M. (2012). In vitro antibacterial activity of leaf extracts of Rhizophoramucronata L. against multi drug resistant Vibrio spp. isolated from marine 
water Lobster's larvae hatcheries. Indian Journal of Geo-Marine Sciences, vol. 41, no. 3, pp.218-222.

Chandrasekaran, M., Kannathasan, K., Venkatesalu, V., and Prabhakar, K. (2009). Antibacterial activity of salt marsh halophytes and mangrove plant against methicillin resistant staphylococcus aureus. World Journal of Microbiology and Biotechnology, vol. 25, pp. 155-160S.

Chapman, V.J. (1976). Mangrove vegetation. Vaduz J. Cramer, pp.447.

Choudhury, S., Sree, A., Mukherjee, S.C., Pattnaik, P., and M. Bapuji, (2005). Invitro antibacterial activity of extracts of selected marine algae and mangrove against fish pathogens. Asian Fisheries Science, vol. 18, pp. 285-294.

Citarasu, T. (2010). Herbal biomedicines: a new opportunity for aquaculture industry. Aquaculture International, vol. 18, no. 3, pp.403-414.

Das, S.T.K., Samantaray, D., Mahapatra, A. P., Pal, N., Munda, R., Thatoi, H. (2018). Pharmacological activities of leaf and bark extracts of medicinal mangrove plant Avicenniaofficinalis L. Clinical Phytoscience, vol. 4, no. 13, pp. 2-10.

Das, S.T.K., Samantaray, D., and Thatoi, H. (2014). Ethnomedicinal, Antimicrobial and Antidiarrheal studies on the mangrove plants of the Genus Xylocarpus: A mini Review, Journal of Bioanalysis\& BiomedicineS12.

Deivanai, S., Bindusara, A.S., G., and Bhore, J. (2014). Culturable bacterial endophytes isolated from Mangrove tree (Rhizophoraapiculata Blume) enhance seedling growth in Rice. Journal of Natural Science, Biology and Medicine, vol. 5, no. 2, pp. 437-444.

Dhayanithi, B., AjithKumar, T.T., Arockiaraj, J., Balasundaram, C., and Harikrishnan, R (2015a). Dietary supplementation of Avicenniamarina extract on immune protection and disease resistance in Amphiprionsabae against Vibrio alginolyticus. Fish and Shellfish Immunology, vol. 45, no. 1, pp. 52-58.

Dhayanithi, .B.,Ajithkumar, T.T., Arockiaraj, J., C. Balasundaram, C., and H. Ramasamy, H. (2015b). Immune protection by Rhizophoraapiculata in clownfish against Vibrioalginolyticus. Aquaculture, vol. 446, no. 1, pp. 1-6.

Eldeen, I.M.S., and Effendy, M.A.W. (2013). "Antimicrobial agents from mangrove plants and their endophytes," in Microbial pathogens and strategies for combating them: science, technology and education (A. Méndez-Vilas Ed.) Formatexpp. 872-882. 
García-Aguilar, N. (2013). Uso de medicamentos veterinarios, productos químicos y alternativos en camaronicultura. Capítulo 6. In: Morales Covarrubias MS (ed.) Camaronicultura de baja salinidad. Trillas, México, pp. 92-109.

Iwu, M.M., Duncan, A.R., and Okunji, C.O. (1999). New antimicrobials of plant origin, In: Janick J. (ed.). Perspectives of new crops and new uses. ASHS Press, Alexandria, VA, pp. 457-462.

Jassim. S.A.A., and Naji, M.A. (2003). Novel antiviral agents: a medicinal plant perspective. Journal Applied Microbiology, vol. 95, pp. 412-427.

Joel,E.L., andBhimba, V. (2010). Isolation and characterization of secondary metabolites from the mangrove plant Rhizophoramucronata, Asian Pacific Journal of Tropical Medicine, vol. 3 , no. 8,pp. 602-604.

Julkipli, R.R., Batubara, G.E., Jogia, I., Batubara, K.A., Audah, and K.N. Nunuk,K.N. (2018) “ Introduction of bioprospecting opportunities for Indonesian mangrove species," IOP Conference Series: Earth and Environmental Science vol. 183, 012013.

Kathiresan, K. (2012). Importance of mangrove ecosystem. International Journal of Marine Science, vol. 2, no. 10, pp. 70-89.

Kathiresan, K., and Rajendran, N. (2005). "Mangrove ecosystems of the Indian ocean region. Indian Journal of Marine Science, vol. 34, no. 1, pp. 104-113.

Khafagi, I., Gab-Alla, A., Salama, W., and Fouda, M. (2003). Biological activities and phytochemical constituents of the gray mangrove Avicenniamarina (Forssk.) Vierh. Egyptian Journal of Biology, vol. 5, pp. 62-69.

Kumar, P. J., and Nath, T.H. (2011). "Metabolic diversity and bioactivity screening of mangrove plants: a review," Acta Physiology plant, vol.33, pp. 1051-1061.

Laith, A.A., Najiah, M., Zain, S.M., Effendy, A.W., Sifzizul, T.M., Nadirah, M., Habsah, M. (2012). Antimicrobial activities of selected mangrove plants on fish pathogenic bacteria. Journal of Animal and Veterinary Advance, vol. 11, no. 2, pp. 234-240.

Le, X., Munekageb Y., and S. Kato, S. (2005). Antibiotic resistance in bacteria from shrimp farming in mangrove areas. Science of the Total Environment, vol. 349: pp. 95-105.

Lim, S.H., Darah, I., and Jain, K. (2006). Antimicrobial activities of tannins extracted from R. apiculate barks. Journal of Tropical Forest Science, vol.18, no. 1, pp. 59-65. 
Manilal, A., Sujith, S., Seghal, J., Kiran, J., Selvin, J and Shakir, C. (2009). Biopotentials of mangroves collected from the southwest coast of India. Global Journal of Biotechnology and Biochemistry, vol. 4, no. 1, pp. 59-65.

Manilal, A., Sujith, S., Selvin, J., kiran G.S., hakir, C., and Lipton, A.P. (2010). Antimicrobial potential of marine organisms collected from the southwest coast of India against multiresistant human and shrimp pathogens. Scientia marina, vol. 74, no. 2, pp. 287-296.

Manilal, A., and Idhayadhulla, A. (2014a). Potential in vitro antimicrobial efficacy of Holigarnaarnottiana (Hook F)," Asian Pacific Journal of Tropical Biomedicine, vol. 4, no. 1, pp. 25-29.

Manilal, A., Merdekios, B., Kambivelikkakath, J., Velappan,,Idhayadhulla, A., Muthukumar, C., Melkie, M. (2014b). An in vitro efficacy validation of mangrove associates, Journal of Coastal Life Medicine, vol. 2 no. 7, pp. 560-565.

Manilal, A., Merdekios, B., Idhayadhulla, A., Muthukumar, C., and Melkie, M. (2015a). An in vitro antagonistic efficacy validation of Rizophoramucronata,Asian Pacific Journal of Tropical Disease, vol. 5 no. 1, pp. 28-32.

Manilal, A., Merdekios, B., Gezmu, T., and Idhayadhulla, A. (2015b). An in vitro antibacterial and anticandidal activity of Sonneratia alga (J. Smith),Thalassas, vol. 31 no. 2, pp. 6773.

Manilal, A., Tsallaa, T., Z. Zerdo, Z., Ameyaa, G., Merdekiosa, B., Johnb, S.E. (2016). Evaluating the antibacterial and anticandidal potency of mangrove Avicennia marina," Asian Pacific Journal of Tropical Disease, vol. 6, no. 2, pp. 930-934.

Meléndez-Rentería, N., Rodríguez-Herrera, R., Aguilar-González, R., Silva-Vázquez, R., and Nevárez-Moorillon, G. (2009). El orégano Mexicano," Cienciacierta, no. 20, pp1-3.

Morales-Covarrubias, M.S. 2010. Detección mediante análisis en fresco e histopatología. Enfermedades del Camarón," 2a Trillas-CIAD México pp. 1-130.

Morales-Covarrubias. M.S., and Gómez-Gil, B. (2014). Enfermedades bacterianas de camarones. In: Morales V, Cuéllar-Angel J. (eds.) Guía técnica-patología e inmunología de camarones penaeidos. OIRSA, Panamá, pp. 167-197.

Morales-Covarrubias, M.S., García-Aguilar, N., Bolan-Mejía, M.C., and Puello-Cruz, A.C. 2016. Evaluation of medicinal plants and colloidal silver efficiency against Vibrio parahaemolyticus infection in Litopenaeusvannamei cultured at low salinity, Diseases of Aquatic Organisms, vol. 22, no.122, and pp.57-67. 
Morales-Covarrubias, M.S., Cuéllar-Anjel, J., Varela-Mejías A., and Elizondo-Ovares, C. 2018. Shrimp Bacterial Infections in Latin America: A Review. Asian Fisheries Science 31S, pp. 76-87.

Nabeel, M.A., Kathiresan, K., and S. Manivannan, S. (2010). Antidiabetic activity of the mangrove species Ceriopsdecandra in alloxan-induced diabetic rats," Journal of Diabetes, vol. 2, no. 2 pp. $97-103$.

Nadarajah, S., and Flaaten, O. (2017). Global aquaculture growth and institutional quality, Marine Policy, vol. 84, pp. 142-15.

Nagababu, P., and Rao, V.U. (2017). Pharmacological assessment, green synthesis and characterization of silver nanoparticles of SonneratiaapetalaBuch.-Ham. Leaves, Journal of applied pharmaceutical Science, vol.7, no.8, pp. 175-182.

Patra, J.K., and Mohanta, Y.K. 12014). Antimicrobial compounds from mangrove plants: A pharmaceutical prospective, Chinese Journal of Integrated traditional and western Medicine, vol. 4, pp. 311-320.

Patra, J.K., and Thatoi, H.N. (2011). Metabolic diversity and Bioactivity screening of mangrove plants: a review, ActaPhysiologiaePlantarum, vol.33, no.4, pp.1051-1061.

Priyono, A., Ilminingtyas, D., Mohson. Y.L.S., Yuliani, L.S., and Hakim, T.L. (2010). Beragamprodukolahanberbahandasar mangrove. Various food products of processed mangrove, Semarang:KeSEMaT. Indonesia pp. 50.

Rajagopal, P.L., Premaletha, K., Sreejith, K.R., Aneeshia, S. (2017). Therapeutic utility of mangroves a Comprehensive Review, International Journal of Applied Pharmaceutical and Biological Research, vol. 2, no. 1, pp. 66-76.

Raju, P.V.R., and Sreeramulu, K. (2017). Antimicrobial activity of marine resources against the fish pathogens isolated from Mugilcephalus, International Journal of Fisheries and Aquaculture Sciences, vol. 7, no. 1, pp. 1-13.

Ramírez, L.S., and Castaño, D.M. (2009). Metodologías para evaluar in vitro la actividad antibacteriana de compuesto de origen vegetal, Scientia et Technica, year XV, no. 42, pp. 263-268.

Regalado, A.I., Sánchez, L.M., Mancebo, B. (2016). Rhizophora mangle, L. (mangle rojo): Una especie con potencialidades de uso terapéutico, Journal of Pharmacy\&PharmacognosyResearch, vol. 4, no. 1, pp. 1-17.

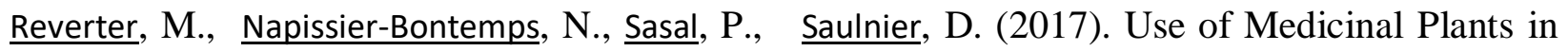
Aquaculture, Diagnosis and control of diseases of fish and shellfish, First Edition, Brian Austin and AweedaNewaj- Fyzul (editors). 
Rosulva, I., Haryadi, Y., and Hastarini, E. (2014). Application of Edible Coating Bases Extract of Lindur (Bruguieragymnorrhiza) and Chitosan on Peeled Off Shrimp, Asian Journal of Agriculture and Food Science, vol. 2, no. 2, pp. 73-82.

Sánchez-Perera, L.M., Varcalcel, L., A. Escobar, A., and Noa, M. (2007). Polyphenol and Phytosterol Composition in an Antibacterial Extract from Rhizophora mangle, Journal of Herbal Pharmacotherapy, vol. 7, pp. 107-128.

Salini, G. (2015). Pharmacological profile of mangrove endophytes- a review, International Journal and Pharmaceutical Sciences, vol.7, no.1, pp.6-15.

Saranraj, P., Stella, D., Sathiyaseelan, K., and Sajani, S. (2010). Antibacterial potentiality of Ethanol and Ethyl acetate extract of Acalyphaindica against human pathogenic bacteria, Journal of Ecobiotechnology, vol. 2, no. 7, pp. 23-27.

Saranraj, P., and Sujitha, D. (2015). Mangrove Medicinal plants: A Review, American-Eurasian Journal of Toxicological Sciences vol.7, no.3, pp.146-156.

Simlai, A., Rai, A., Mishra, S., Mukherjeel, K., and Roy, A. (2014). Antimicrobial and antioxidative activities in the bark extracts of Sonneratiacaseolaris, a mangrove plant, EXCLI Journal, vol.13, pp. 997-1010.

Sreenivasa, R.M., Teja, G., Sirisha, I.R., and Yedukondala, R.P. (2015). Screening of antimicrobial activity of mangrove plant Acanthus ilicifolius on shrimp and fish pathogens, Asian Journal of Plant Science and Research, vol. 5, no. 5, pp. 1-3.

Sudheer, N.S., Philip, R., and Bright Singh, I.S. (2011). In vivo screening of mangrove plants for anti WSSV activity in Penaeusmonodon, and evaluation of Ceriopstagal as a potential source of antiviral molecules," Aquaculture, vol. 311, pp. 36-41.

Sudheer, N.S., R. Philip, R., and Bright Singh, I.S. (2012). Anti-white spot syndrome virus activity of Ceriopstagal aqueous extract in giant tiger shrimp Penaeusmonodon," Archives of Virology, vol. 157, pp. 1665-1675.

Suganthy, N., Pandian, S.K., and Devi, K.P.(2009). Cholinesterase inhibitory effects of Rhizophoralamarckii, Avicenniaofficinalis, SesuviumportulacastrumandSuaedamonica: Mangroves inhabiting an Indian coastalarea (Veellar Estuary), Journal of Enzyme Inhibition and Medicinal Chemistry, vol. 24, no. 3 pp. 702-707.

Thatoi, H., Behera, B.B., and Mishra, R.R. (2013). Ecological role and biotechnological potential of mangrove fungi: a review," Mycology, vol. 4, no.1, pp. 54-71.

Torres Rojas, M.L., Arias Palacios, J., Guatibonza, F., Oliveros, A.I., and FernandezLopez, C. (2007). Análisis microbiológico de plantas medicinales con óxido de etileno, Revista Cubana de Farmacia, vol. 41, no.2, pp.1-3. 
Tu, H.T., Silvestre, F., Phuong, N.T., and Kestemont, P. (2010). Effects of pesticides and antibiotics on penaeid shrimp with special emphases on behavioral and biomarker responses," Environmental Toxicology and Chemistry, vol. 29, no. 4, pp. 929-938.

Vadlapudi, V., and Naidu, C. (2009). In vitro antimicrobial potentiality of mangrove plant Myriostachyawigtiana against selected phytopathogens, Biomedical and pharmacology journal, vol. 2, no. 2, pp. 235-238.

Vignesh, R., Karthikeyan, B.S., Periyasamy, N., and Devanathan, K. (2011). Antibiotics in aquaculture: An overview, South Asian Journal Experimental Biology, vol. 1, no.3, pp.17.

Watts, J.E.M., Schreier, H.J., Lanska, L., and M.S. Hale, M.S. (2017). The Rising Tide of Antimicrobial Resistance in Aquaculture: Sources, Sinks and Solutions, Marine Drugs, vol. 15 , no. 6, pp.1-16. 